* Professor adjunto da Faculdade de Direito da Universidade Federal de Santa Catarina (UFSC). Exprofessor da Faculdade de Direito na Universidade de Brasília (UnB), da faculdade de direito da Universidade Federal de Juiz de Fora (UFJF) e do Curso de Direito Universidade Estadual de Londrina (UEL). Possui doutorado e mestrado em Direito pela Universidade Federal de Santa Catarina (2006), tendo realizado estágio de doutoramento (2004) na Universidade de Lisboa, e graduação em Direito pela Universidade Federal de Mato Grosso (1995).

E-mail: claudioladeira@hotmail. com

** Mestra em Teoria e História do Direito e doutoranda em Direito Constitucional pelo Programa de Pós-graduação em Direito da Universidade Federal de Santa Catarina.

E-mail: marjamangili@gmail.com

\section{A Restrição da Imunidade Parlamentar na ADI 5526: uma Crítica ao Controle Judicial de Constitucionalidade a Partir da Análise do VOTO DO MIN. LUí́s ROBERTO BARROSO}

\author{
The Restriction Of Parliamentary Immunity In The \\ Adi 5526: A Critique Of Judicial Review From The \\ Analysis Of Min. Luís Roberto Barroso Vote
}

\section{Claudio Ladeira de Oliveira* Marja Mangili Laurindo**}

Como citar: OLIVEIRA, Claudio Ladeira de; LAURINDO, Marja Mangili. A restrição da imunidade parlamentar na adi 5526: uma crítica ao controle judicial de constitucionalidade a partir da análise do voto do min. Luís Roberto Barroso. Revista do Direito Público, Londrina, v. 14, n. 3, p. 110-130, dez. 2019. DOI: $10.5433 / 24157-108104-1.2019 v 14 n 3 p .110$. ISSN: 1980$511 \mathrm{X}$

Resumo: Este artigo tem como objetivo a análise crítica do voto do Ministro Luís Roberto Barroso na Ação Direta de Inconstitucionalidade 5526, que versou sobre se o alcance das medidas cautelares diferentes de prisão, quando aplicadas aos congressistas, seriam passíveis de revisão pelo Poder Legislativo - tal e qual ocorre com a prisão em flagrante. O instituto da imunidade parlamentar tem o propósito de proteger a autonomia democrática do Legislativo com relação ao Poder Judiciário, delimitando seu poder de interferência. Concluiu-se que não houve motivos razoáveis para se acreditar que a expansão das medidas do art. 319 do CPP restringiria tal garantia estabelecida constitucionalmente ao parlamento. A ADI 5526 se mostra como caso sintomático do modo de funcionamento do Supremo Tribunal Federal com relação ao seu modo de atuação em direção aos demais poderes, em especial o legislativo. Nesse sentido, este artigo apoia-se sobre a perspectiva de Dimoulis e Lunardi, bem como de Waldron, acerca dos limites do controle judicial de constitucionalidade para apontar a distância entre o discurso do voto do Min. Barroso e a legitimidade política jurisdicionaldo seu controle de constitucionalidade. 
Palavras-chave: ADI 5526. Controle judicial de constitucionalidade. Luís Roberto Barroso.

Abstract: This paper critically analyzes the vote of the Supreme Court Minister Luís Roberto Barroso in the ADI 5526, which prescribes different precautionary measures for the arrest for congressmen and congresswomen, which would be subject to the revision of the Legislative Power. Furthermore, the purpose of parliamentary immunity is to protect the democratic autonomy of the legislature in relation to the judiciary, diminishing its power of interference. This paper concludes that the expansion of article 319 of the CPP does not restrict the constitutionally established guarantee of parliamentary immunity. Henceforth, ADI 5526 proves a symptomatic case of how the Federal Supreme Court treats other branches of government, especially the legislative branch. In this sense, this paper utilizes the perspective of Dimoulis and Lunardi, as well as Waldron, in order to understand the limits of judicial control of constitutionality in order to point out the difference between the Barroso's vote and the jurisdictional political legitimacy of its control of constitutionality.

Keywords: ADI 5526. Judicial Review. Luís Roberto Barroso. 


\section{INTRODUÇÃO}

O Supremo Tribunal Federal tem decidido diversas questões de alcance moral e político extremamente controvertidas ${ }^{1}$. Alçado à tarefa democrática de guardião dos interesses constitucionais, garantiu-se a ele a competência da decisão contramajoritária. Nos anos que se sucederam à promulgação da Constituição Cidadã, o exercício da jurisdição constitucional ganhou evidência, tanto no sentido de ter-se tornado um dos centros de promoção de uma série de ações favoráveis a direitos e políticas públicas quanto pelo alcance de suas sessões televisionadas.

Impulsionada pelo constitucionalismo contemporâneo, o Supremo Tribunal Federal e seus ministros se tornaram protagonistas da política nacional. Hoje, se fala no seu ativo papel ilustrado, impulsionador do progresso histórico em um país dominado por séculos de oligarquias (BARROSO, 2018).

Nesse sentido, a análise do voto de um de seus ministros, no caso, Luís Roberto Barroso, dada na Ação Direta de Inconstitucionalidade 5526, em conjunto com a leitura de outras falas, como a realizada por meio da Folha de S. Paulo (BARROSO, 2018), pode se mostrar esclarecedora do contexto atual quanto à atuação e extensão dos poderes do STF. Pleiteou-se, pela referida ação, que as medidas cautelares diversas da prisão estabelecidas em 2011 pelo art. 319 do Código de Processo Penal, também passassem, de acordo com a ideia de imunidade parlamentar disposta pelo art. 53 da Constituição Federal pela análise do Poder Legislativo.

O Ministro Barroso entendeu que as medidas do art. 319 do Código de Processo Penal podem ser diretamente impostas aos parlamentares, isto é, sem consideração dos procedimentos relativos à imunidade parlamentar, sob alegação de que tais medidas não dificultariam ou impediriam o exercício regular de mandato dos congressistas ${ }^{2}$.

Em um primeiro momento, far-se-á uma breve introdução ao conceito e ao histórico da imunidade parlamentar no Brasil; em seguida,uma análise do voto em questão, a fim de conhecer os seus fundamentos e sopesar se a argumentação se atêm ao texto constitucional no que se refere ao instituto de imunidade parlamentar. Por último, se promove uma leitura crítica da fundamentação do Ministro utilizada em seu voto, bem como do texto 'Operação Abafa' tenta barrar avanços do STF, escreve Barroso, publicado no jornal Folha de S. Paulo, em que o autor explicita seu entendimento sobre sua função, com base nos textos de Dimitri Dimoulis, Soraya Lunardi e Jeremy Waldron acerca dos limites do controle judicial de constitucionalidade promovido por Tribunais Constitucionais.

\footnotetext{
1 A exemplo do próprio objeto deste artigo, bem como o direito ao aborto de fetos anencéfalos, a constitucionalidade da Marcha da Maconha, dentre outras. Conferir em 'STF: um tribunal amigo 'apenas'de liberdades individuais de autonomia privada?" (IOTTI, 2016).

2 O Plenário do Supremo Tribunal Federal (STF) decidiu que o Poder Judiciário tem competência para impor a parlamentares as medidas cautelares do artigo 319 do Código de Processo Penal (CPP). Somente quando houver imposição de medida que dificulte ou impeça, direta ou indiretamente, o exercício regular do mandato, a decisão judicial deveria ser encaminhada para apreciação legislativa. Pelo entendimento da maioria, apenas a medida que suspenda ou dificulte o exercício de mandato deve ser conduzida para decisão Legislativa. Nesse sentido, o voto de Barroso, que pedia improcedência total do pedido, foi vencido.
} 


\section{A IMUNIDADE PARLAMENTAR COMO OBJETO HISTÓRICO DEMOCRÁTICO E OBJETO DA ADI 5526}

A imunidade parlamentar, instituto reconhecido em grande parte das democracias ocidentais, também tem seu lugar e seu peso na história constitucional brasileira. Criada com o objetivo de garantir aos integrantes eleitos do Poder Legislativo a liberdade necessária para o cumprimento das funções representativas em um espaço democrático, isenta de algumas responsabilidades os parlamentares com relação ao exercício de sua função. Seu surgimento está atrelado à efetivação da separação dos Poderes à autonomia ao Poder Legislativo, assegurando-lhe independência necessária para a persecução dos interesses e pautas políticas. Serve, assim, como um sistema de proteção contra possíveis medidas intimidatórias por parte do Executivo e, também, do Judiciário. Costuma ser, portanto, um instrumento comum aos Estados de Direito democráticos.

Em um espectro amplo, tal garantia se manteve ao longo do tempo ${ }^{3}$, tendo sofrido restrições nos períodos ditatoriais ${ }^{4}$. A Constituição de 1988 tratou de assegurar tal instituto no Título IV (“Organização dos Poderes”), Capítulo I ("Do Poder Legislativo”), Seção V ("Dos Deputados e dos senadores"), cuidando dos seus aspectos material e formal, através do Art. 53 (reformado pela EC no 35/2001), pelo qual determina que compete às Casas parlamentares resolver a prisão de seus membros, caso tenham eles tenham sido detidos em flagrante por crime inafiançável (art. 53, $\S 2^{\circ}$ ), bem como estabelece que as Casas tem poder para suspender o andamento de ação penal após a diplomação de congressista (art. $53, \S 3^{\circ}$ ). Tais regras teriam por fim assegurar que qualquer medida do Poder Judiciário que tenha poder de interferir no exercício do mandato parlamentar deve, obrigatoriamente, ser objeto de deliberação anterior do Legislativo.

Tal disposição não havia sido analisada após a Lei 12.403, de 2011, que ampliou o rol de medidas cautelares do Código de Processo Penal em 2011, pelos artigos 312 e 319. Por meio deles foram criadas medidas restritivas intermediárias que estabelecem medidas alternativas à prisão, que incluem, por exemplo, a possibilidade de afastamento de função pública.

Na AC 4070, julgada em 2016, o STF já havia reconhecido o cabimento das medidas cautelares aos congressistas amparado sobre o "princípio da inafastabilidade da jurisdição"; interpretou, desta forma, que é cabível a aplicação de medidas cautelares como o afastamento de parlamentares das funções públicas. Tendo em vista que a decisão no caso a AC 4070 criou um novo entendimento que expandiu o rol de possíveis penas aos parlamentares, a Ação Direta de Inconstitucionalidade 5526 pleiteou que tais medidas cautelares diversas da prisão também

3 Presente no ordenamento nacional desde a primeira Constituição, de 1824, pela qual se afirmou que "os Membros de cada uma das Câmaras são invioláveis pelas opiniões, que proferirem no exercício das suas funcções", a imunidade parlamentar sofreu algumas alterações conforme outras Constituições foram outorgadas ou promulgadas. Em 1891, por exemplo, a Constituição passou a prever que não apenas as opiniões, mas também palavras e votos proferidos no exercício do mandato estariam amparados pela imunidade parlamentar.

4 A Constituição de 1937, apesar de não prever isenção de responsabilidade civil e criminal por difamação, calúnia, injúria, ultraje à moral pública ou provocação pública ao crime, assegurava que "só perante a sua respectiva Câmara responderão os membros do Parlamento nacional pelas opiniões e votos que emitirem no exercício de suas funções". Em 1967, apesar de materialmente limitado tal instituto, manteve-se formalmente a imunidade parlamentar ao se prever que "os membros do Congresso Nacional não poderão ser presos, salvo flagrante de crime inafiançável, nem processados criminalmente, sem prévia licença de sua Câmara.", situação que se alteraria posteriormente com o Ato Institucional $\mathrm{n}^{\circ} 5$. 
passassem pela análise das Casas às quais interessam. A pergunta que o STF deveria responder, pautada pela ADI, é se tais medidas cautelares diferentes de prisão, quando aplicadas aos congressistas, seriam passíveis de revisão pelo Poder Legislativo.

$\mathrm{O}$ assunto já havia sido tratado indiretamente em três momentos, quando foram julgados o ex-deputado e à época presidente da Câmara dos Deputados, Eduardo Cunha (do à época PMDB), o ex-senador Delcídio do Amaral (PT) e, mais recentemente, o senador Aécio Neves (PSDB), todos judicialmente afastados de seus cargos. Envolvendo questões de dimensão política nacional de tal tamanho, o instituto da imunidade parlamentar passou a ser cada vez mais visado.

Através da já mencionada Ação Direta de Inconstitucionalidade, ajuizada pelos Partido Progressista (PP), Partido Social Cristão (PSC) e Solidariedade (SD), foi requerido ao Supremo Tribunal Federal que as medidas previstas nos artigos 312 e 319 do Código de Processo Penal fossem, quando aplicadas aos parlamentares, também submetidas à análise do Congresso Nacional em um prazo de 24 horas.

Segundo os impetrantes, a Constituição autoriza a Câmara e o Senado a decidirem a respeito da perda do mandato político nos casos de infrações previstas na própria Constituição (art. $55, \S 1^{\circ}$ e $\S 2^{\circ}$ ). Afirma que compete às Casas parlamentares resolver a prisão de seus membros quando tenham sido detidos em flagrante por crime inafiançável (art. 53, $\S 2^{\circ}$ ) e garante que as Casas têm poder para suspender o andamento de ação penal após a diplomação de congressista $\left(\right.$ art. $53, \S 3^{\circ}$ ).

O julgamento da questão mostra que, se a princípio a ideia forte era proteger o Poder Legislativo das intromissões dos demais Poderes, o discurso da imunidade parlamentar não como prerrogativa democrática, mas privilégio penal que isentaria os parlamentares de serem responsabilizados em escândalos de corrupção, tem ganhado força e um portador à sua altura: o Judiciário.

$\mathrm{O}$ voto de Barroso, que visou a improcedência total do pedido em julgamento, acabou vencido pelos demais, e o resultado da ação se deu no sentido de que o Poder Judiciário tem competência para impor a parlamentares as medidas cautelares do artigo 319 do CPP, exceto nos casos em que se veja dificultado ou impedido, direta ou indiretamente, o exercício regular do mandato, isto é, decidiu-se pela procedência parcial da ação.

O Ministro observou que a imposição pelo Judiciário de medidas cautelares diversas da prisão a parlamentares não necessita do aval do Legislativo. A análise do voto de Barroso, no presente caso, pode servir como uma pequena amostra de como tem decidido de uma maneira geral, principalmente através do apontamento de quais tipos de argumento tem se utilizado para fundamentar suas sentenças. Além disso, acredita-se que, por ser um ministro com alta visibilidade acadêmica, tendo publicado uma série de textos doutrinários e bem como seu visível engajamento e exposição midiática pela sua causa, a compreensão de seu modo de votar pode indicar não apenas um modo de decidir pessoal, mas como um fragmento do modus operandi do próprio Judiciário. 


\section{O VOTO DE BARROSO: ILUMINISMO NO EXERCÍCIO DO CONTROLE JUDICIAL DE CONSTITUCIONALIDADE OU DO REI-FILÓSOFO}

Tecida no pensamento clássico, o rei-filósofo é uma figura política cujos conhecimentos filosóficos garantiriam os bons rumos da pólis. Na modernidade, ressurgiu amparada pelos ideais filosóficos de pensadores que se colocavam contra a irracionalidade do Antigo Regime, cuja legitimidade se sustentava por justificativas transcendentais, ora divinas, ora amparadas pela Razão. Eventualmente, tal crítica serviu à Revolução Francesa, que poria abaixo as antigas estruturas.

As alterações de percepção provocadas pelo Iluminismo sobre a concepção de mundo e de homem atingiram as compreensões jurídicas de sua época. Sorvendo-se de pensadores liberais como Locke, os iluministas vislumbraram a possibilidade de garantir igualdade e liberdade em lei. O direito consuetudinário foi considerado, por esses, como sendo uma má herança dos tempos do medievo, um direito que não havia sido submetido ao processo de racionalização, sendo puramente uma expressão de uma série de tradições sem qualquer fundamento consistente, ou mesmo irracionais. Era preciso sistematizar aquilo que atendia aos novos preceitos do pensamento burguês: a ideia de que todos os homens nascem iguais por natureza, ou melhor, todos os homens são iguais juridicamente. No âmbito da jurisprudência dos novos tempos, portanto, os juízes seriam limitados pelas leis, afinal, "a Revolução tinha sido feita também contra a tirania dos juízes que, apoiados no caráter casuísta e flexível do direito tradicional, tornavam o direito num saber hermético, cujos resultados eram imprevisíveis e incontroláveis pelos cidadãos." (HESPANHA, 2005 , p. 347). Isso porque, no medievo, o direito provinha de fontes cuja legitimidade se sustentava na "autoridade técnica ou doutrinal dos especialistas, capazes de revelar um direito que residia nas próprias coisas ou nos princípios abstratos da razão.” (HESPANHA, 2005, p. 349).

$\mathrm{Na}$ Corte brasileira do século XXI, há quem defenda que o papel do juiz constitucional é o de garantir uma razão humanista que "empurre a história" diretamente para um "processo civilizatório". Considerando-se um conjunto de argumentações em plenário, declarações à imprensa, textos e decisões judiciais, o ministro Luís Roberto Barroso tem sido o porta-voz da crença de que, legitimados pelo conhecimento específico e pelo mérito próprio de sua função, o Supremo Tribunal Federal deve garantir, por meio dos seus instrumentos, que se faça "justiça". Comumente, tal pretensão se ampara em discursos como o de defesa dos direitos fundamentais e o de combate à corrupção, frequentemente levantados como motivos para a cruzada do ministro.

Em continuidade à promoção do papel político e reformador do Poder Judiciário, Barroso julgou, na ADI 5526, improcedente o pedido dos partidos Progressista (PP), Social Cristão (PSC) e Solidariedade, que pediram ao Supremo Tribunal Federal interpretação conforme a Constituição a fim de que a aplicação a parlamentares das medidas cautelares estabelecidas nos artigos 312 e 319 do CPP fosse encaminhada ao Legislativo para apreciação, por maioria, em 24 horas.

A questão da imunidade parlamentar é, aparentemente, assunto já bem tratado pela doutrina jurídica nacional. Francisco Campos, em que pese sua posição controversa, em meados do século XX já se preocupava em estabelecer os limites da competência do Poder Judiciário quanto a "definir 
e especificar os privilégios parlamentares, delimitando-lhes os efeitos e a extensão" (CAMPOS, 1956). Para Campos, questões de economia interna das assembleias são de competência exclusiva delas mesmas, já que de não se poderia vislumbrar sua independência quando as matérias de sua competência estivessem subordinadas a uma jurisdição estranha (CAMPOS, 1956, p. 115). Para o autor, ao Poder Judiciário só competiria determinar se o Poder Legislativo "se conformou, na sua elaboração, às formalidades ou aos processos estatuídos às deliberações legislativas." (CAMPOS, 1956, p. 118). A interferência do judiciário nos assuntos de prerrogativa legislativa significaria o fim da discriminação de competências estabelecido pelo princípio da separação dos poderes, já que "não pode haver discriminação de competências onde uma única competência absorve, pela sua universalidade, as demais competências com ela e em face dela instituídas." (CAMPOS, 1956, p. 119). Se a Constituição estabelece os poderes de cada órgão e determina a autonomia do Poder Legislativo quanto às questões relativas à interrupção do mandato de seus integrantes, estabelecendo em segundo plano, subsidiariamente, a atuação do Poder Judiciário e, quando este, contrariando tal ordem de disposições, atenta contra a independência do primeiro, é evidente que, ao "Instituir, portanto, ao lado desta, outra competência, cobrindo o mesmo campo e exercendo-se sobre o mesmo objeto, seria neutralizar ou nulificar a primeira.” (CAMPOS, 1956, p. 120).

Em contraposição, Luís Roberto Barroso parece acreditar que seu encargo histórico autoriza a sua ideia de que "a eliminação da imunidade referida é necessária se se pretende por termo à impunidade no país" (BARROSO, 2018), da qual se utiliza para fundamentar o voto pelo qual afirma que as únicas exceções constitucionais expressamente previstas no tocante à tramitação de processos crime contra parlamentares estão no art. 53, $\S 2^{\circ}$ e 3 , bem como o art. 55, $\S 2$, que versam sobre a prisão de crime inafiançável, sustação de ação penal e deliberação de perda de mandato.

Barroso inicia os fundamentos de seu voto com o exemplar caso do Senador Aécio Neves, sobre o qual recaiu uma "ação cautelar a fim de prendê-lo, bem como denúncia por crimes de corrupção passiva e pelo crime previsto no art. $2^{\circ}, \S 1^{\circ}$ da Lei de Organização Criminosa" (BARROSO, 2018). A $1^{\text {a }}$ Turma decidiu que Neves, diferentemente dos demais réus, seria afastado do exercício de seu mandato e estaria obrigado a recolher-se em seu domicílio no período noturno, como estabelecem as medidas cautelares distintas da prisão estabelecidas pelo CPP.

Afirma Barroso (2017b, p. 4) que: “[...] o afastamento de um parlamentar do cargo é medida excepcionalíssima. Porém, impedir o Judiciário de intervir em hipótese em que o mandato popular está claramente sendo utilizado para cometer crimes violaria o princípio republicano e qualquer ideia mínima de justiça."

Procurando manter a coerência quanto ao defendido papel ilustrado do STF, sobre uma conjuntura em que é "preciso empurrar a história" (BARROSO, 2018) ou, ainda, sobre "momentos cruciais do processo civilizatório", diz Barroso que "a razão humanista precisa impor-se sobre o senso comum majoritário":

Em nome da defesa da "transformação dos costumes no país", caberia ao Poder Judiciário

5 “O direito não pode ser interpretado fora da realidade em que está inserido. E o momento atual é o da revelação de 
encarnar a ideia de que "É preciso que um órgão não eletivo ajude a dar o salto histórico necessário." (BARROSO, 2018).

Dada a oportunidade para a interpretação dos referidos dispositivos penais, Barroso não hesitou de fazer valer, em cumprimento da sua função de "contrapeso" dos Poderes, uma interpretação de modo a estabelecer que a independência das Casas quanto à sustação do andamento do processo e a deliberação de perda de mandato parlamentar, conforme os artigos 53, § 2 e 3, e 55, VI, §2, se referiria apenas ao caso de prisão em flagrante. Isto é, ainda que as medidas cautelares não sejam interpretadas restritivamente, a autonomia parlamentar deve ser.

Partindo da ideia de que o "espírito" da EC no 35/2001 (que retirou da Constituição de 88 a exigência de aprovação prévia do Parlamento dos processos criminais) tinha por intuito "por termo à impunidade no país" (conforme PEC n 101/1995), o ministro defende que, com exceção daquilo que está expresso no texto constitucional, "o processo criminal contra parlamentar instaurado perante o Supremo Tribunal Federal deve transcorrer como nas instâncias ordinárias, sem nenhuma interferência do Poder Legislativo." Assim, sendo as medidas cautelares válidas para os Parlamentares - ainda que não se encontrem expressas no texto constitucional - a interpretação favorável à autonomia parlamentar deve ser interpretada restritivamente. A aplicação da lei independe da autorização da Casa Parlamentar respectiva, tanto para a instauração do processo quanto para o seu desenvolvimento regular, inclusive no que diz respeito à imposição de medidas cautelares.

Parece justo, aos olhos do progresso histórico, que direitos constitucionais sejam restringidos por "interpretações restritivas", enquanto instrumentos de sanção possam ser ampliados por "interpretações expansivas".

As medidas cautelares previstas pelo CPP entram, claramente, em conflito com as prerrogativas parlamentares. A possibilidade de suspensão do exercício da função pública "quando houver justo receio de sua utilização para a prática de infrações penais", prevista no art. 319, VI, é a mais evidente delas; o recolhimento domiciliar noturno, de forma diversa, também tem a capacidade de interferir nas atividades legislativas. Conforme o voto de Barroso, tais medidas são excepcionalíssimas, assim como "excepcionalíssima há de ser o fato de um parlamentar utilizar o cargo para a prática de crimes"; além do mais, o recolhimento noturno "não interfere com a rotina funcional, porque permite o trabalho e a convivência com as pessoas" mas que "restringe frequência a baladas, restaurantes, recepções e outros momentos festivos" (BARROSO, 2017b, p. 9).

No sentido de afirmar a "injustiça" e "incongruência" da determinação da prisão das demais pessoas envolvidas no mesmo processo que manteve imune o Senador Aécio Neves, o ministro apela para a máxima do jusnaturalista Gustav Radbruch (1997, p. x): “A injustiça extrema não pode ser direito.” Em o que se mostra como um verdadeiro sofismo, afirma que "a Constituição tampouco estabelece que parlamentar tenha obrigação de pagar tributos, possa se divorciar ou ser

esquemas espantosos de corrupção sistêmica e endêmica no país. Resta saber, portanto, se a Constituição deve ser interpretada de modo a permitir que a sociedade brasileira enfrente este mal ou se, ao contrário, deve ser interpretada de modo a se criar o máximo de embaraço à transformação dos costumes no país.” BARROSO, 2018). 
réu em reclamação trabalhista. Ou seja: em tudo o que não está previsto na Constituição, está sujeito às mesmas normas que qualquer cidadão."

Tal argumento foge de qualquer lógica jurídica. É evidente que a Constituição não dispõe sobre os deveres ou direitos acima mencionados com relação ao caso particular dos parlamentares: seria totalmente desnecessário. Afinal, tais direitos e deveres dizem respeito aos cidadãos em geral, categoria na qual estão inseridos também os parlamentares. $\mathrm{O}$ contrário, no entanto, não é verdadeiro: não são todos os cidadãos que possuem o direito de imunidade parlamentar, que é explicitamente garantido pela Constituição Federal de 88.

Se as medidas cautelares não foram descritas pela Constituição e sobre elas parece haver lacuna quanto à aplicação ao caso específico dos parlamentares, por outro lado o art. $53 \S 3^{\circ}$ dispõe - após garantir em seu caput a inviolabilidade civil e penal daqueles -, ipsis litteris, que:

Recebida a denúncia contra Senador ou Deputado, por crime ocorrido após a diplomação, o Supremo Tribunal Federal dará ciência à Casa respectiva, que, por iniciativa de partido político nela representado e pelo voto da maioria de seus membros, poderá, até a decisão final, sustar o andamento da ação (BRASIL, 1988).

Não há que se falar, aqui, em situação "não prevista". É evidente que a Constituição visa garantir, por meio de tal artigo, a imunidade parlamentar não apenas nos casos em que a denúncia enseje prisão; que o caput anuncia, de antemão, o objetivo do artigo: assegurar imunidade parlamentar ante o Poder Judiciário. A questão implicada por Barroso de que as medidas incluídas no CCP pela reforma de 2011 não estão expressamente previstas pela Constituição (por óbvio, já que elas são o próprio objeto de análise da ADI) também é frágil, porque, como visto, tampouco está previsto que tais medidas não caibam no guarda-chuva daquele artigo constitucional.

Como seria lógico imaginar, se a Constituição, em seu art. 53, $\S 2^{\circ}$, estabelece que "Os Deputados e Senadores são invioláveis, civil e penalmente, por quaisquer de suas opiniões, palavras e votos" e "Desde a expedição do diploma, os membros do Congresso Nacional não poderão ser presos, salvo em flagrante de crime inafiançável. Nesse caso, os autos serão remetidos dentro de vinte e quatro horas à Casa respectiva, para que, pelo voto da maioria de seus membros, resolva sobre a prisão" (BRASIL, 1988), no que concerne à pena de prisão, seria esperado que quanto às medidas penais cautelares previstas no art. 319 do CPP a regra constitucional mantivesse o mesmo efeito esperado do caso de prisão em flagrante.

A possibilidade de que as medidas previstas pelo art. 312 (prisão preventiva) e pelo inciso VI, do art. 319 do CPP (suspensão do exercício de função pública) sejam aplicadas sem o visto parlamentar constitucionalmente requerido atravessa diretamente autonomia do Parlamento quando a decisão que impede exercício regular de mandato parte unicamente do Poder Judiciário. Afinal, é possível falar em garantia da autonomia do Poder Legislativo quando há possibilidade de que o Poder Judiciário interfira para além do que está previsto constitucionalmente?

O objetivo dos artigos da Constituição que preveem o instituto da imunidade parlamentar 
é justamente que o Legislativo mantenha autonomia com relação ao Poder Judiciário, delimitando, portanto, seu poder de interferência, limitado pelas próprias Casas legislativas quando a elas é dado o poder de decidir. Ainda que a Constituição não preveja as medidas cautelares estabelecidas pelo CPP com sua reforma, não haveria motivos razoáveis para acreditar que com a adoção de tais medidas a autonomia estabelecida constitucionalmente deveria ser revisada.

É evidente que eventuais medidas que igualmente têm o poder de interferir sobre a atividade dos legisladores deveriam estar submetidas aos mesmos critérios de apreciação pelas Casas. Ou, nas palavras da petição inicial da ADI 5526: não sendo lícito o afastamento de parlamentar em razão de delito em flagrante sem consulta ao Parlamento no prazo de 24 horas, porque seria lícito afastamento sem consulta por ações que preveem medidas cautelares quando, no fim, as implicações são as mesmas em ambos os casos?

Se tal argumento carece de juridicidade, sustenta-se unicamente por um outro tipo de argumento, de apelação moral, que atravessa todo o discurso do ministro em seu voto. Diz Barroso (2017b, p. 12) que: "Há uma imensa demanda na sociedade brasileira por integridade, patriotismo e idealismo. Somos um país que se perdeu na história e precisa reencontrar o seu rumo. Não se trata de uma questão política. É uma questão prévia às escolhas políticas."

Tal pensamento autoriza o ministro a afirmar, sem constrangimento, que "O Supremo Tribunal Federal tem dado contribuição importante para o enfrentamento desse estado de coisas, ainda que de forma menos vigorosa do que pessoalmente acho que deveria." (BARROSO, 2018).

Nesse sentido, é preciso analisar criticamente a atuação e a leitura do papel do STF e de seus ministros como agentes não meramente jurídicos de mudanças sociais.

\section{O SUPREMO TRIBUNAL FEDERAL COMO AUTORIDADE DEMOCRÁTICA ARGUMENTATIVA}

A judicialização da política é um fenômeno que parece surgir a partir de duas frentes: se é possível falar em uma crescente demanda por parte da sociedade, incluindo aí demandas do órgão representativo por excelência, o legislativo - e também o executivo -, é também possível afirmar que os órgãos da instância judiciária, como o Supremo Tribunal Federal, tomam para si cada vez mais a iniciativa de resolução de questões políticas. Inclusive por meio de interpretação constitucional. No Brasil, declarações do tipo "é preciso que um órgão não eletivo ajude a dar o salto histórico necessário.", quando partem de um ministro do Supremo Tribunal Federal, provocam a pergunta pelos alcance e limite de tal politicidade.

A partir da Constituição de 1988 e da adoção de uma nova proposta hermenêutica adotada pelos juristas brasileiros, bem como também a reforma do judiciário pela EC/45 no ano de 2004, que ampliou o poder legiferante do STF através de instrumentos a Súmula Vinculante, o Poder Judiciário parece estar amparado teoricamente para decidir mais propriamente criando ou alterando leis do que propriamente julgando conforme a Constituição. A ideia de um judiciário que resolve querelas políticas, provocado ou propositivamente, cresce amparada por declarações como a acima 
mencionada: o STF seria o agente competente para promover progresso. Estariam os ministros autorizados a interpretar a Constituição de maneira enviesada sob o pretexto de "acelerar" a história? Ou melhor: estaria o Supremo autorizado a decidir, em nome de tal progresso, contra legem?

Mas o que confere ao Poder Judiciário esse papel de decidir politicamente em detrimento dos demais poderes?

Em A razão sem voto: o Supremo Tribunal Federal e o governo da maioria (BARROSO, 2017a), o ministro propõe que, em certos casos em que o processo político majoritário não dê conta da função de "empurrar a história", caberia ao STF garanti-la, a fim de, por outros meios que não o representativo via voto, sejam efetivados o próprio entendimento da maioria e a igualdade de dignidade entre os cidadãos.

Barroso não nega, nesse texto, a importância essencial de uma democracia representativa de viés político-legislativo majoritário. Porém, não tarda em explicar que a democracia ultrapassa os aspectos formais, englobando também uma dimensão substantiva relativa aos direitos fundamentais, que é atravessada por outra dimensão, de cunho deliberativo, argumentativo e persuasivo. Assim, diz que "a democracia contemporânea, portanto, exige votos, direitos e razões." (BARROSO, 2017a) como fundamento para a defesa da ideia de que apesar de o Legislativo "ter preferência em atuar", quando não aja, "a atribuição seria transferida para o Judiciário", caso em que o papel da corte, diante disso - reforça o autor - deve ser iluminista.

No Brasil, durante o período da Ditadura Militar, o direito constitucional foi encarado por teorias que rejeitavam sua normatividade, seja a partir de um ponto de vista conservador, seja crítico $^{6}$. Além disso, afirma que existia uma "patologia persistente, representada pela insinceridade constitucional" (BARROSO, 2017a, p. 29), que fazia da Constituição simples aparato ideológico, "repleta de promessas que não seriam honradas".

A teoria neoconstitucional advinda do pós-segunda-guerra europeu e, no Brasil, com o fim daquele regime ditatorial, teria alterado esse cenário com a proposição de um novo direito constitucional, pós-positivista, reivindicante de uma normatividade real por meio de uma nova leitura sobre a função jurisdicional constitucional. Para além de preservar os direitos já conquistados, o novo constitucionalismo - ou constitucionalismo democrático - também teria caráter promocional, "constituindo-se em instrumento de avanço social” (BARROSO, 2017a, p. 31), transformando-se na "ideologia vitoriosa do século XX" (BARROSO, 2017a, p. 33).

A complexidade das novas relações também demandou uma figura responsável pela decisão entre possíveis conflitos entre direitos fundamentais e soberania popular, capaz de decidir em um mundo onde "mazelas como o tráfico de drogas e de armas, o terrorismo e a multiplicação de conflitos internos e regionais" consomem "vidas, sonhos e projetos de um mundo melhor." (BARROSO, 2017a, p. 37).

Em meio ao processo de judicialização da vida, os tribunais são chamados a responder

$6 \mathrm{O}$ autor cita as correntes historicistas, que teriam tratado tal questão a partir de uma mera leitura descritiva dos fatos, e a crítica marxista, que teria se retirado do campo do direito (BARROSO, 2017a). 
casos difíceis, questões não são teóricas, mas concretas, sem previsão legal, o que é natural, já que o constituinte e o legislador não são capazes de prever todas as situações possíveis. Disso, decorreria a necessidade de que a função jurisdicional não se atenha apenas à abstração do texto da norma, mas também à realidade, quebrando as barreiras entre legislação, política, jurisdição e direito (BARROSO, 2017a, p. 39).

Tal situação se resolveria pela atuação judicial lógica e argumentativamente, com auxílio dos parâmetros normativos, jurisprudenciais e elementos não-jurídicos. Frisa o ministro que "toda decisão judicial precisa ser reconduzida a uma norma jurídica. Trata-se de um trabalho de construção de sentido, e não de invenção de um Direito novo" (BARROSO, 2017a, p. 39), construção essa que se dá por meio de ponderação e argumentação jurídica, que são atravessadas pela escolha de uma possível solução valorativa comportada pelo ordenamento (BARROSO, 2017a, p. 41).

Sobre discricionariedade, vale citar integralmente:

Discricionariedade, porém, é um conceito tradicional do direito administrativo, no qual está embutido o juízo de conveniência e oportunidade a ser feito pelo agente público. Nessa acepção, discricionariedade significa liberdade de escolha entre diferentes possibilidades legítimas de atuação, uma opção entre "indiferentes jurídicos". Nesse sentido, inexiste discricionariedade judicial. O juiz não faz escolhas livres nem suas decisões são estritamente políticas. Essa constitui uma das distinções mais cruciais entre o positivismo e o não positivismo. Para Kelsen, principal referência do positivismo normativista romano-germânico, o ordenamento jurídico forneceria, em muitos casos, apenas moldura, conjunto de possibilidades decisórias legítimas. A escolha de uma dessas possibilidades, continua ele, seria um ato político, isto é, plenamente discricionário. A concepção não positivista, compreendida neste estudo, afasta-se desse ponto de vista. Com efeito, o Direito é informado por uma pretensão de correção moral, pela busca de justiça, da solução constitucionalmente adequada. Essa ideia de justiça, em sentido amplo, é delimitada por coordenadas específicas, que incluem a justiça do caso concreto, a segurança jurídica e a dignidade humana. Vale dizer: juízes não fazem escolhas livres, pois são pautados por esses valores, todos eles com lastro constitucional (BARROSO, 2017a, p. 42-43).

A ideia de uma única resposta possível proposta por Dworkin também não faria sentido na medida em que não haveria uma única resposta correta, isto é, uma verdade a ser encontrada pelo juiz. Aqui, de maneira incisiva, Barroso reforça a soberania do intérprete constitucional: "se houver força externa ao intérprete, com o poder de chancelar a verdade proclamada, será inevitável reconhecer que ela é filha da autoridade" (BARROSO, 2017a, p. 43-44).

As funções atribuídas ao STF pelo art. 102 da CF/88 teriam estabelecido a função político institucional contramajoritária e representativa ao órgão. A função contramajoritária, diz Barroso, tem sido exercida parcimoniosamente, tendo em vista o número de leis declaradas parcial ou totalmente inconstitucionais desde 88 , agindo o Tribunal em autocontenção e em respeito às decisões legislativas e executivas, como nos casos das Ações Afirmativas.

Se Barroso reforça a ideia de um STF que atua em respeito à ideia da representação 
legislativa em sua função autocontida, pergunta pela relação entre democracia e princípio majoritário, ou melhor, se os atos legislativos são representativos, de fato, de uma maioria (BARROSO, 2017a, p. 51). Seria difícil deduzir isso de um cenário onde "disfuncionalidade, corrupção, captura por interesses privados são temas globalmente associados à atividade política." 78 (BARROSO, 2017a, p. 52).

Assim,

No geral, o processo político majoritário se move por interesses, ao passo que a lógica democrática se inspira em valores. E, muitas vezes, só restará o Judiciário para preservá-los. O deficit democrático do Judiciário, decorrente da dificuldade contramajoritária, não é necessariamente maior que o do Legislativo, cuja composição pode estar afetada por disfunções diversas, dentre as quais o uso da máquina administrativa, o abuso do poder econômico, a manipulação dos meios de comunicação (BARROSO, 2005, p. 41).

Os juízes teriam se tornado, então, mais representativos que os parlamentares dos desejos do povo. Já se vive, diz Barroso, em uma sociedade que "se identifica mais com seus juízes do que com seus parlamentares", e isso seria perceptível tanto pela atenção que se dá aos debates no STF em detrimento dos ocorridos no legislativo (BARROSO, 2017a, p. 53), quanto pela democratização dos cursos de direito, que permitiriam que pessoas de origens sociais variadas ingressassem na magistratura (BARROSO, 2017a, p. 56). A democracia, portanto, não se daria apenas nos espaços tradicionais: ela se daria por votos, mas também por argumentos, caso em que o STF poderia ser um melhor intérprete do sentimento majoritário (BARROSO, 2017a, p. 55).

Segundo o autor, os juízes ocupam funções vitalícias, longe de circunstâncias de curto prazo e "tentações populistas", atuando sempre por provocação dos interessados, julgando somente aquilo que foi requerido, sempre acompanhado pelo dever de fundamentar suas decisões. Também o mérito de terem sido aprovados em "concursos árduos e competitivos", garantiria a qualificação desse tipo de serviço público (BARROSO, 2017a, p. 58). Outrossim, prevê-se hoje instrumentos como o amicus curiae, capazes de aproximar o judiciário dos interesses populares (BARROSO, 2017a, p. 56-57).

Ressaltando o caráter de razão e correção das sentenças judiciais tal como proposto por Alexy, se refere à corte constitucional como representante argumentativo da sociedade. Decisões jurídicas sempre tem objetivo de correção e podem ser aceitas via argumentativa por uma

7 No mesmo sentido com relação à efetividade, o ministro diz que "Ao longo dos anos, a ampla exposição das disfunções do financiamento eleitoral, das relações oblíquas entre Executivo e parlamentares e do exercício de cargos públicos para benefício próprio revelou as mazelas de um sistema que gera muita indignação e poucos resultados" (BARROSO, 2017a, p. 52).

8 A doutrina da dificuldade contramajoritária, estudada anteriormente, assenta-se na premissa de que as decisões dos órgãos eletivos, como o Congresso Nacional, seriam sempre expressão da vontade majoritária. E que, ao revés, as decisões proferidas por uma corte suprema, cujos membros não são eleitos, jamais seriam. Qualquer estudo empírico desacreditaria as duas proposições. Por numerosas razões, o Legislativo nem sempre expressa o sentimento da maioria. Além do já mencionado déficit democrático resultante das falhas do sistema eleitoral e partidário, é possível apontar algumas outras. Em primeiro lugar, minorias parlamentares podem funcionar como veto players, obstruindo o processamento da vontade da própria maioria parlamentar. Em outros casos, o autointeresse da Casa legislativa leva-a a decisões que frustram o sentimento popular. Além disso, parlamentos em todo o mundo estão sujeitos à captura eventual por interesses especiais, eufemismo que identifica o atendimento a interesses de certos agentes influentes do ponto de vista político ou econômico, ainda quando em conflito com o interesse coletivo." (BARROSO, 2017a, p. 55). 
legitimação discursiva projeto do constitucionalismo democrático (BARROSO, 2017a, p. 57).

Barroso compreende que o papel de vanguarda iluminista está para além do papel puramente representativo: ele é responsável por empurrar a história quando ela emperra. Por isso, "uma crítica formulada com base em uma visão formal da democracia, mas sem povo, não deve impressionar." (BARROSO, 2017a, p. 66).

Mesmo com críticas por "excesso de ativismo","a Corte acaba realizando, em fatias, de modo incompleto e sem possibilidade de sistematização, a reforma política que a sociedade clama" (BARROSO, 2017a, p. 58-59).

O discurso de Barroso suprime sem qualquer receio uma linha entre aquilo que é jurídico daquilo que é político sem, contudo, atentar para quaisquer possibilidades de crítica aos seus argumentos. Tal crítica, no entanto, se faz necessária.

\section{A LEGITIMAÇÃO DO SUPREMO TRIBUNAL: DEMOCRÁTICA OU JURÍDICA?}

Os argumentos trazidos por Barroso, em especial quanto à representatividade racionalargumentativa, podem ser analisados sob outras perspectivas.

Primeiramente, sob o argumento de uma necessidade de efetivação dos direitos constitucionais $^{9}$, fala-se em uma ampliação do papel judicial na democracia brasileira, sobretudo em razão da inefetividade e pouca dignidade do Poder Legislativo, apontando para uma aproximação entre uma nova forma democrática representativa por intermédio dos magistrados, capazes, por sua formação e mérito, de alcançar o sentimento majoritário. Menciona, também, que a democratização permitiu uma ampliação das origens sociais dos juízes.

Com relação a esse último argumento, embora seja verdade que houve uma democratização dos cursos de direito, uma recente pesquisa do Conselho Nacional de Justiça (2018) esclarece o perfil dos magistrados no Brasil: a grande esmagadora maioria é composta por homens brancos, casados, pais, heterossexuais, com mais de 40 anos. Para Dimoulis e Lunardi (2017, p. 205-206), a justiça constitucional é uma "instituição elitista em termos de recrutamento e função social", sendo pouco provável que levará em consideração interesses de classes populares de maneira mais intensa e eficiente do que os poderes periodicamente eleitos e submetidos a controle popular.

Ao apontar que o Parlamento não parece representar a população nos seus interesses, não parece fazer parte da preocupação do ministro informar, tampouco, como é possível medir que a representatividade do STF é maior e está mais de acordo com o "sentimento majoritário".

Segundo ainda Dimoulis e Lunardi (2017), a tentativa de fundamentar politicamente e democraticamente suas decisões, o STF se distancia de sua função jurisdicional de corte constitucional. Acreditam que a legitimação do STF não seria político-democrática: processo de controle jurisdicional de constitucionalidade que se diz legitimar por tais meios só poderia ser uma negação da "aplicação de regras e limitações típicas do processo judicial”" (DIMOULIS; LUNARDI,

9 Cf. "Por uma história constitucional brasileira: uma crítica pontual à doutrina da efetividade" (LYNCH; MENDONÇA, 2017). 


\section{4}

A RESTRIÇÃO DA IMUNIDADE PARLAMENTAR NA ADI 5526: UMA CRÍTICA AO CONTROLE JUDICIAL DE

CONSTITUCIONALIDADE A PARTIR DA ANÁLISE DO VOTO DO MIN. LUÍS ROBERTO BARROSO

2017, p. 198), próprias do ato jurisdicional. Sua atuação, portanto, deve se resumir à área jurídica, afinal, não há qualquer previsão de que sua atuação deva flutuar conforme manifestações populares: o Supremo tem a função de controlar as decisões dos demais poderes que estejam em suspeição no que se refere à sua constitucionalidade, o que significa justamente pensa-lo, em essência, sob tais limitações (DIMOULIS; LUNARDI, 2017).

Também em consonância com uma ideia limitada de atuação dos Tribunais em $O$ conceito de Direito, de Hart, seus poderes seriam "intersticiais", sujeitos a "constrangimentos substantivos" (DIMOULIS; LUNARDI, 2017). O controle jurisdicional de constitucionalidade não possui natureza legislativa, o que significa dizer que não pode ser encarado a partir da visão de que se trata de um órgão de representação do povo: não é democrático em um primeiro sentido, tampouco político. "Por mais que tenha origem e finalidade política, a Constituição é um texto de validade e efeitos jurídicos" (DIMOULIS; LUNARDI, 2017, p. 199), que tem por objetivo primeiro a garantia da ordem constitucional sobre o ordenamento, e tal função só é possível a partir da compreensão do que é processo judicial e do respeito aos seus procedimentos e às normas no que tange à fundamentação jurídica.

Afinal,

[...] o argumento básico para legitimar a justiça constitucional é justamente a democracia representativa. Por mais que possam ser feitos questionamentos sobre a qualidade da democracia e a qualidade da legislação na atualidade, há consenso social de que as leis são (e devem ser) elaboradas pelo Legislativo como legítimo representante popular, conforme a Constituição. (DIMOULIS; LUNARDI, 2017, p. 200).

Se a Constituição de 88 foi promulgada pelos representantes do povo, caberia ao STF apenas o papel de proteger a vontade desses representantes (DIMOULIS; LUNARDI, 2017, p. 201).

Porém, em uma leitura mais atenta ao ativismo judicial nesses processos constitucionais, os autores afirmam que STF seria ativista na "utilização de formas de interpretação e de ação processual que aumentam os poderes dos magistrados", porém passivista ${ }^{10}$ no controle constitucional de fiscalização e modificação de decisões do Legislativo (DIMOULIS; LUNARDI, 2017, p. 207).

A crítica contra a postura contramajoritária do STF seria, então, fraca. O STF seria um tribunal politicamente passivo, porque pouco questiona decisões de política econômica e social desses poderes ${ }^{11}$. Também a própria autonomia de disposição de pauta, bem como os pedidos

10 Segundo dados dos autores, entre 1988 e 2009 somente $0,98 \%$ de leis federais foram encaradas pelo STF como parcial ou totalmente inconstitucionais por meio de Ação direta de Inconstitucionalidade, o que comprovaria que a maior parte das atuações do Tribunal na prática, não são contramajoritárias com relação às opções políticas e as decisões de coalizões majoritárias entre Legislativo e Executivo (DIMOULIS; LUNARDI, 2017, p. 209-210).

11 Mesmo a atuação do STF sobre medicamentos seria mais um comprovante de tal passividade, já que diversas oportunidades de ativismo de impacto orçamentário muito maior foram evitadas, a exemplo dos assuntos de educação, previdência social, direitos trabalhistas ou, mesmo no plano dos medicamentos para além da interferência nos casos de efeito restrito às ações individuais. Outro indicador desse passivismo seriam os processos de grande relevância política encalhados há anos, como o julgamento da Lei de Anistia, o financiamento de campanha política por pessoas jurídicas, do Código Florestal, e da Lei dos royalties do petróleo (DIMOULIS; LUNARDI, 2017). 
de vista sem prazo para término seriam instrumento que acabariam por "convalidar" opções legislativas e executivas, o que favoreceria a tese de Dimoulis e Lunardi (2017).

Contudo, ainda que a problemática não atravesse, na prática, a discussão sobre uma extrapolação da função contramajoritária do STF, é possível observar uma série de decisões discutíveis que decidem contra o texto constitucional, no que se poderia classificar como declarações de inconstitucionalidade do próprio texto constituciona $1^{12}$. E isso se dá através da forma de ativismo pelo qual se estabelece para o Tribunal Constitucional uma competência interpretativa e legislativa que deságua em criação normativa, que no discurso do Min. Barroso toma ares democráticos representativos legítimos, cujos limites esbarram apenas na ocasião.

No mesmo sentido de compreender a função do Tribunal Constitucional como distante de uma tarefa "democrática", Waldron, em Representative Lawmaking (2008), levanta questões de legitimidade de representação para as questões de produção normativa, defendendo, por fim, que o lugar democrático por excelência seria o Legislativo.

No mundo moderno, diz Waldron (2008), o modelo legislativo é associado à democracia, o que significa normalmente que legisladores são eleitos para representarem e, uma vez não representantes, podem ser substituídos por outros. A eleição com tal propósito dá aos legisladores a legitimidade que os juízes não têm. Porém, casos como juízes eleitos e outros cargos eletivos como o executivo poderem reclamar para si a legitimidade para tanto, e mesmo com casos como o da Câmara dos Lordes, apontam que a questão vai além da legitimidade eleitoral.

Um dos problemas com relação à decisão judicial que se atravessa pela legiferação se dá pela transparência de tal processo. Se o legislativo é publicamente reconhecido pela atividade de legislar, criando e modificando leis, a Corte - ou o Supremo Tribunal - não o é. Ela não foi criada para atender a esse propósito: não possui os instrumentos e recursos que garantam a publicização da atividade, pelo contrário, é publicamente reconhecida por interpretar e aplicar a lei. Diferentemente do processo parlamentar, pelo qual as leis são diretamente criadas ou alteradas, a produção judicial é oblíqua. Usando-se de John Austin para explicar tal situação, Waldron afirma que o juiz legisla julgando, não propriamente legislando (WALDRON, 2008, p. 337).

Assim, embora os juízes legislem, isto é, sejam também criadores e modificadores de leis, não há transparência sobre o procedimento, característica ou virtude própria às instituições legislativas. O conceito de aparelho legislativo é atravessado, em princípio, pela ideia de aplicação do princípio liberal de publicidade.

É do fundamento das sociedades democráticas de direito que o lócus de produção legislativa seja publicamente identificável. Isso porque é necessário que haja clareza sobre o procedimento, uma vez que é comum que propostas legislativas sejam apresentadas sob o disfarce de questão interpretativa. Uma vez colocada como problema interpretativo, o procedimento de criação legislativa remove do campo de participação qualquer poder dos cidadãos de influenciar ou tomar conhecimento dos processos (WALDRON, 2008, p. 339).

12 Como apontado por Dimoulis e Lunardi (2013) em outro artigo, intitulado "A decisão do Supremo Tribunal Federal sobre a união de pessoas do mesmo sexo." 
É preciso falar, também, acerca do número de pessoas envolvidas na legislatura. Um maior número de representantes garante um maior número de interesses envolvidos a serem discutidos, o que é, por si só, um princípio fundamental. Para além de questões principiológicas abstratas, é preciso levar a sério os interesses dos participantes da sociedade. Imaginar que os interesses sociais serão analisados e possivelmente contemplados "por mágica" é negligenciá-los, defende Waldron (2008, p. 344). No entanto, não se trata apenas da transparência dos seus procedimentos e pelo número de seus integrantes. Há que se falar de legitimidade representativa. Waldron (2008) acredita que a representação é apropriada para a produção de normas em abstrato, isto é, normas gerais, capazes de representar aquilo que há de comum entre várias classes, simplificando interesses e assimilando sujeitos. Ou seja: o processo de criação de leis apresenta uma afinidade específica com o modelo representativo próprio do Legislativo, diferentemente das demais esferas de poder.

Paira sobre o legislativo, como bem indica a decisão de Barroso, uma dúvida moral. Como bem adverte Waldron (2008, p. 335), defender uma política de princípios é, sim, desejável, porém também é matéria de princípios que interesses sejam tratados de maneira equânime, e assim só podem ser na medida em que o legislativo exerça tal função.É preciso atentar, antes mesmo do que às qualidades morais e principiológicas do conteúdo de uma decisão, ou meramente à formalidade de seus procedimentos, aos princípios procedimentais, e isso toca a instituição que legisla e os processos dos quais ela se utiliza para legislar. Conquanto os princípios processuais não se usem de fundamentos morais para justificar uma lei, se ocupam de estabelecer o também importante e sumariamente desprezado problema moral que o conceito de legitimidade carrega. No intuito, porém, de acelerar a história e promover o progresso, as formalidades dos processos são atacados como instituições sem alma: lhes faltaria a moralidade que apenas princípios relativos ao conteúdo do direito e as intenções dos magistrados implicam.

Assim, também pela importância moral dos procedimentos, é preciso considerar, além do problema da legitimidade da representação, a necessidade de um explicit lawmaking (legislação explícita, em tradução literal), quer dizer, a publicidade do momento em que uma lei é criada ou alterada.

O contexto da representação legislativa, na contramão de uma "representação argumentativa" de um órgão de Justiça, se pauta tradicionalmente na ideia de desentendimento e deliberação no âmbito da espelhamento dos diferentes tipos de interesses sociais ali em disputa.

No anseio de desfazer as possíveis injustiças decorrentes da atual norma constitucional referente ao instituto da imunidade parlamentar, a decisão aqui estudada da ADI 5526 pareceu ignorar precisamente o que subjaz no propósito da formalidade: a lei não é apenas um fim em si mesma, diz Waldron. A compreensão dos seus fundamentos teóricos levanta, necessariamente, a observação do seu processo e local de criação.

Quanto ao papel contramajoritário atribuído aos ministros do STF por Barroso, parece ser comum ao constitucionalismo contemporâneo encarar a democracia e o poder atribuído às pessoas comuns por meio de seus representantes como seu inimigo natural (WALDRON, 2016, p. 38).

É possível perceber que o maior receio do constitucionalismo atual é contra a ditadura da 
maioria - e não qualquer ditadura, ressalta o autor. A ênfase em uma pretensa opressão da maioria parte da ideia de que se deve preocupar apenas com possíveis abusos do poder democrático, enquanto nada se fala a respeito de uma possível opressão por parte de famílias poderosas ou empresas. Desta forma, ainda que muitos constitucionalistas se usem do termo soberania popular para dar aos limites e constrições constitucionais credenciais contra os abusos do legislativo, o que acontece de fato é que suas reais visões sobre o constitucionalismo se revelam aristocráticas (WALDRON, 2016, p. 39).

Se, de fato, as intenções estão de acordo com os interesses populares, um comprometimento real levaria a esclarecer junto ao povo as eventuais aberturas para entendimentos sobre o texto constitucional. $\mathrm{O}$ que acontece, na prática, é que tais aberturassão decididas por um segmento institucional não-majoritário, o judiciário (WALDRON, 2016, p. 40).

Não obstante a atividade do Supremo Tribunal Federal aparente se restringir aos critérios de sua função interpretativa, a partir do momento que se coloca em pauta aquilo que está em jogo, isto é, matéria de fontes constitucionais, é preciso atentar para a evidência de que o formato e o caráter da constituição está sendo alterada por um corpo que não tem mais legitimidade que os legisladores para falar em nome da soberania popular.

\section{CONSIDERAÇÕES FINAIS}

A decisão aqui estudada é apenas uma dentre tantas outras que toca o muito sensível ponto sobre a atuação do Judiciário.

Se a Constituição de 88 surgia como uma resposta de resistência à Ditadura Militar, cujos anseios republicanos carregaram, em seus artigos, os órgãos públicos de preceitos liberais representativos, atualmente pode-se pensar qual é o papel do Poder Judiciário na manutenção desses mesmos preceitos.

A ADI 5526 é um caso interessante de ser estudado por duas questões que se sobressaem. Em primeiro lugar, é interessante observar a maneira como decide o Min. Luís Roberto Barroso, isto é, atentar a que tipo de fundamentação se utiliza para afirmar o entendimento de restrição ao tradicional instituto constitucional da imunidade parlamentar pelo artigo do Código de Processo Penal. Observou-se que se trata, sobretudo, de uma série de pontuações que recorrem a argumentos de uma pretensa justiça que "antecede o político", pautada em ideias sobre moralidade que atuam em conjunto com outra série de deturpações das normas constitucionais com fins de adequação aos argumentos de justiça.

Em um segundo momento, a ADI 5526 se mostra interessante na medida em que serve como caso sintomático do modo de funcionamento do Supremo Tribunal Federal com relação ao seu modo de atuação em direção aos demais poderes. Em tempos de judicialização da política, uma decisão que restringe um direito democraticamente tradicional e estabelecido pela Constituição vigente e legítima aos membros das Casas Legislativas, sem argumentos jurídicos fortes que sustentem tal posição, demonstra a fragilidade da instituição representativa diante do 
poder judicial e revela as contradições de um constitucionalismo que se pauta teoricamente em uma força normativa da constituição que cede lugar à argumentos para "empurrar a história".

Sob o argumento da efetitividade e racionalidade promovidas pela instituição judicial, Barroso confere à sua própria função a de vanguarda iluminista diante de certos momentos históricos. Não se sabe o que seria e como se daria, exatamente, "empurrar a história", e nem porque concursados teriam maior chance de identificar o sentimento majoritário que conferisse a dignidade que Barroso diz faltar ao legislativo: o certo é que os magistrados saberiam, por sua competência excepcional, conduzir a história para seu fim como República ilustrada.

Os questionamentos de Waldron permitem ver a ausência de valorização da questão procedimental e o ataque ao parlamento enquanto instituição e local público de criação de leis em sentido próprio. Decidindo questões que são atravessadas por interesses políticos fundamentais à sociedade, isto é, julgando a própria extensão do direito de imunidade parlamentar - elemento essencial à democracia brasileira conquistada após longo período de ditadura militar - e, ainda, o fazendo de maneira completamente arbitrária, o Supremo Tribunal Federal necessita ter repensada a extensão da sua atuação. Como parecem querer apontar, ainda, diretamente sobre o cenário nacional, Dimoulis e Lunardi, não cabe ao STF, enquanto tribunal jurídico, qualquer outra coisa que ser democrático senão por vias juridicamente constitucionais.

O lugar de um ministro do Supremo Tribunal Federal é de grande privilégio. Detentor da competência para emitir a interpretação correta do texto constitucional, pode usar-se de seu poder para conferir sentidos completamente distintos daqueles preconizados em princípio, restringindo direitos não apenas dos representantes eleitos, mas também atentando diretamente contra a autonomia política popular ao eleger-se como representante ilustrado dos interesses da nação.

\section{REFERÊNCIAS}

BARROSO, Luís Roberto. 'Operação abafa' tenta barrar avanços do STF, escreve Barroso.

Folha de São Paulo, São Paulo, 23 fev. 2018. Ilustríssima. Disponível em: https://www1. folha.uol.com.br/ilustrissima/2018/02/em-artigo-ministro-do-supremo-rebate-criticas-feitas-aotribunal.shtml?loggedpaywall. Acesso em: 15 jul. 2018.

BARROSO, Luís Roberto. A razão sem voto: o Supremo Tribunal Federal e o governo da maioria. In: VIEIRA, Oscar Vilhena; GLEZER, Rubens (org.). A razão e o voto: diálogos constitucionais com Luís Roberto Barroso. Rio de Janeiro: FGV, 2017. p. 25-78.

BARROSO, Luís Roberto. ADI 5526: Anotações para o voto. 2017. Disponível em: https:// luisrobertobarroso.com.br/wp-content/uploads/2017/10/ADI-5.526-Anota\%C3\%A7\%C3\%B5espara-o-voto-2.pdf. Acesso em: 15 jul. 2018.

BARROSO, Luís Roberto. Neoconstitucionalismo e constitucionalização do Direito (o triunfo tardio do Direito Constitucional no Brasil). Revista de Direito Administrativo, São Paulo, v. 240, p. 1-42, 2005.

BRASIL. [Constituição (1988)]. Constituição da República Federativa do Brasil de 1988. 
Brasília: Presidência da República, 1988. Disponível em: http://www.planalto.gov.br/Ccivil_03/ Constituicao/Constituicao67.htm. Acesso em 15 jul. 2018.

BRASIL. Decreto-lei no 3.689, de 3 de outubro de 1941. Código de Processo Penal. Rio de Janeiro: Presidência da República, 1941. Disponível em: http://www.planalto.gov.br/ccivil_03/ Decreto-LEi/Del3689.htm. Acesso em: 31 jul. 2018.

BRASIL. Supremo Tribunal Federal. ADI 5526. Relator Min. Alexandre de Moraes. Data de protocolo:16 maio 2016. Disponível em: http://redir.stf.jus.br/estfvisualizadorpub/jsp/ consultarprocessoeletronico/ConsultarProcessoEletronico.jsf?seqobjetoincidente $=4982736$. Acesso em: 31 jul. 2018.

CAMPOS, Francisco. Direito constitucional. São Paulo: Livraria Freitas Bastos, 1956.

CONSELHO NACIONAL DE JUSTIÇA. Perfil Sociodemográfico dos

Magistrados Brasileiros 2018. 2018. Disponível em: http://cnj.jus.br/files/conteudo/ arquivo/2018/09/49b47a6cf9185359256c22766d5076eb.pdf. Acesso em: 24 set. 2018.

DIMOULIS, Dimitri; LUNARDI, Soraya. A decisão do Supremo Tribunal Federal sobre a união de pessoas do mesmo sexo. In: ANJOS FILHO, Robério (org.). STF e direitos fundamentais. Salvador: Juspodivm, 2013.

DIMOULIS, Dimitri; LUNARDI, Soraya. Democraticidade ou juridicidade? Reflexões sobre o passivismo do STF e o futuro do controle judicial de constitucionalidade. In: VIEIRA, Oscar Vilhena; GLEZER, Rubens (org.). A razão e o voto: diálogos constitucionais com Luís Roberto Barroso. Rio de Janeiro: FGV, 2017. p. 197-223.

HESPANHA, António Manuel. Cultura jurídica europeia: síntese de um milênio. Florianópolis: Fundação Boiteux, 2005.

IOTTI, Paulo. STF:um tribunal amigo 'apenas' de liberdades individuais de autonomia privada? Justificando, 28 out. 2016. Disponível em: http:/justificando.cartacapital.com.br/2016/10/28/ stf-um-tribunal-amigo-apenas-de-liberdades-individuais-de-autonomia-privada/. Acesso em 21 set. 2018.

LYNCH, Christian Edward Cyril; MENDONÇA, José Vicente Santos de. Por uma história constitucional brasileira: uma crítica pontual à doutrina da efetividade. Direito e Práxis, Rio de Janeiro, v.8, n. 2, 2017. Disponível em: http://www.scielo.br/pdf/rdp/v8n2/2179-8966rdp-8-2-974.pdf. Acesso em: 24 set. 2018.

RADBRUCH, Gustav. Cinco minutos de filosofia do direito. In: RADBRUCH, Gustav. Filosofia do direito. 6. ed. Coimbra: Arménio Amado, 1997.

WALDRON, Jeremy. Political political theory. Cambridge: Harvard University Press, 2016.

WALDRON, Jeremy. Representative lawmaking. Boston: Boston University, 2008. Disponível em: http://www.bu.edu/law/journals-archive/bulr/volume89n2/documents/WALDRON.pdf. Acesso em: 20 abr. 2018.

Como citar: OLIVEIRA, Claudio Ladeira de; LAURINDO, Marja Mangili. A restrição da imunidade parlamentar na adi 5526: uma crítica ao controle judicial de constitucionalidade a partir 
da análise do voto do min. Luís Roberto Barroso. Revista do Direito Público, Londrina, v. 14, n. 3, p. 110-130, dez. 2019. DOI: 10.5433/24157-108104-1.2019v14n3p. 110. ISSN: 1980-511X

Recebido em: 24/10/2018

Aprovado em: 03/06/2019 